\title{
Effects of a rumen-protected mixture of conjugated linoleic acids on hepatic expression of genes involved in lipid metabolism in dairy cows
}

\author{
G. Schlegel, ${ }^{\star}$ R. Ringseis, ${ }^{*}$ W. Windisch,† F. J. Schwarz,† and K. Eder ${ }^{\star 1}$ \\ *Institute of Animal Nutrition and Nutrition Physiology, Justus-Liebig-University Giessen, Heinrich-Buff-Ring 26-32, D-35392 Giessen, Germany \\ †Department of Animal Sciences, Chair of Animal Nutrition, Technical University of Munich, Liesel-Beckmann-Straße 6, D-85350 Freising- \\ Weihenstephan, Germany
}

\begin{abstract}
Supplementation of conjugated linoleic acids (CLA) reduces milk fat content in dairy cows and, thus, may be a useful dietary strategy to improve energy balance during early lactation. The present study was performed to investigate whether supplementation of CLA could have adverse effects on hepatic lipid metabolism such as observed in rodents. For this aim, 40 Holstein cows were allotted to 2 groups, which were fed daily $172 \mathrm{~g}$ of either a CLA-free, rumen-protected control fat (control group) or a rumen-protected CLA fat supplying $4.3 \mathrm{~g}$ of cis-9,trans-11 CLA and $3.8 \mathrm{~g}$ of trans-10,cis-12 CLA per day (CLA group). To identify potential changes of lipid metabolism, expression of several genes involved in lipid metabolism was determined in liver biopsy samples taken at wk 5 of lactation, using a whole-genome gene chip. In the CLA group, milk fat content and daily milk fat yield were lower than in the control group. Milk yield was higher, whereas fat-corrected milk and energy-corrected milk were lower in the CLA group than in the control group. The CLA group, moreover, had an improved energy balance. To study potential effects of CLA on hepatic lipid metabolism, we considered 6 genes encoding fatty acid transporters, 7 genes involved in intracellular fatty acid transport, 21 and 7 genes, respectively, involved in mitochondrial and peroxisomal $\beta$-oxidation, 6 genes of carnitine metabolism, 3 genes of ketogenesis, 21 genes involved in fatty acid and triacylglycerol synthesis, 17 genes involved in cholesterol metabolism, and 20 genes involved in lipoprotein metabolism. None of these genes was differentially regulated between the CLA group and the control group. Gene chip data were confirmed by quantitative PCR analysis, which revealed no difference in the expression of key enzymes of various pathways such as lipogenesis, $\beta$-oxidation, and ketogenesis between the 2 groups of cows. In line with those find-
\end{abstract}

Received August 15, 2011.

Accepted March 9, 2012.

${ }^{1}$ Corresponding author: klaus.eder@ernaehrung.uni-giessen.de ings, concentrations of triacylglycerols and cholesterol in liver and plasma were not different between the 2 groups of cows. In conclusion, the present study shows that CLA supplementation at a dose effective for milk fat depression does not induce adverse effects on hepatic lipid metabolism in dairy cows.

Key words: conjugated linoleic acid, dairy cow, gene expression, hepatic lipid metabolism

\section{INTRODUCTION}

During early lactation, dairy cows are typically in a negative energy balance (NEB) as food intake capacity is limited and the amount of energy consumed does not meet the high energy requirement for maintenance and milk production (Drackley, 1999). As NEB in dairy cows is associated with metabolic disorders and reproductive failures, attempts are made to reduce the gap between energy intake and energy requirement. One of them is to increase energy intake by elevating the amounts of concentrates or by addition of fats. However, these dietary strategies have several drawbacks such as a reduction of DMI or an increased risk of rumen acidosis (Hayirli and Grummer, 2004; Kay et al., 2006). Thus, a more promising attempt to improve NEB is to lower energy output via the milk (e.g., by reduction of the content of fat, the nutrient which is most variable and moreover represents the major energy cost in milk production; Bauman and Davis, 1974; Kay et al., 2006). The use of dietary conjugated linoleic acid (CLA) supplements is well known to lower milk fat content, not only in dairy cows but also in several other species such as pigs or rats, with trans-10,cis-12 CLA being the isomer responsible for this effect (Bauman et al., 2008). It has been well established that trans-10, cis-12 CLA lowers milk fat content mainly by an inhibition of de novo FA synthesis in the mammary gland, and also by a reduction of uptake of FA from triacylglycerolrich lipoproteins due to inhibition of lipoprotein lipase (Bauman et al., 2011). Recently, it has been shown that the use of dietary CLA supplements indeed improves NEB by decreasing energy output via the milk and, 
thus, provides a promising dietary strategy to prevent health problems associated with NEB in dairy cows (Kay et al., 2006; Odens et al., 2007; Schwarz et al., 2007). However, for practical use, aspects of safety must be considered, particularly with respect to possible adverse side effects of CLA on metabolism.

Studies in laboratory animals such as rats and mice have shown that CLA exhibits several beneficial properties, such as anticarcinogenic, antiatherogenic, and antidiabetogenic effects (Ha et al., 1987; Lee et al., 1994; Houseknecht et al., 1998). However, besides these beneficial effects, some serious adverse side effects were observed. In mice, supplementation of trans-10, cis-12 CLA led to dramatic changes in hepatic lipid metabolism, resulting in the development of fatty liver (Belury and Kempa-Steczko, 1997; Tsuboyama-Kasaoka et al., 2000; Clément et al., 2002). Interestingly, this phenomenon was not observed in other species such as rats or hamsters (Stangl, 2000; Giudetti et al., 2005; Miranda et al., 2009), indicating that the response to CLA on hepatic lipid metabolism is species specific.

During early lactation, hepatic lipid metabolism is generally stressed by a great amount of FA released from adipose tissue and subsequently taken up into the liver. These FA cannot be completely oxidized or released into the blood as triacylglycerols (TAG) via very low-density lipoproteins (VLDL). Thus, during early lactation, TAG accumulate in the liver (Katoh, 2002). Therefore, a potential adverse effect of CLA on hepatic lipid metabolism during this critical phase requires particular attention in dairy cows. In dairy cows, many studies have been performed to investigate metabolic effects of dietary CLA. Most of these studies focused on the effects of CLA on the metabolism of mammary gland, particularly milk fat synthesis and fat content of milk (e.g., Baumgard et al., 2002b; Loor and Herbein, 2003; Moore et al., 2004; Piperova et al., 2004; Moore et al., 2005; Odens et al., 2007; Perfield et al., 2007; Medeiros et al., 2010; Weerasinghe et al., 2012) and the metabolism of adipose tissue (e.g., Baumgard et al., 2002a, Harvatine et al., 2009; Akter et al., 2011). In contrast, a few studies dealing with the effect of CLA on hepatic metabolism show that supplementation of CLA does not influence hepatic total lipid content (Bernal-Santos et al., 2003; Selberg et al., 2004; Castañeda-Gutiérrez et al., 2005). However, as lipid metabolism is very complex and includes several pathways such as uptake, oxidation, and synthesis of FA, assembly and secretion of lipoproteins or ketogenesis, the finding of an unchanged hepatic TAG concentration does not necessarily mean that CLA has no adverse effects on specific pathways of lipid metabolism. The effect of CLA on hepatic lipid metabolism, however, has not yet been investigated in detail. Therefore, the pres- ent study aimed to investigate the effect of a rumenprotected CLA mixture at a level sufficient to achieve decrease in milk fat on hepatic lipid metabolism. For this purpose, the expression profile of several genes involved in hepatic lipid metabolism was considered, thus allowing us to detect potential changes of critical pathways of lipid metabolism.

\section{MATERIALS AND METHODS}

The animal experiment was conducted at the Agricultural Experimental Station Hirschau of the Technical University of Munich, Germany. It was approved by the Bavarian state animal care and use committee.

\section{Animals}

Forty primi- and multiparous Holstein cows (2.6 \pm 1.1 parities, mean \pm SD) were used as experimental animals for this study. The experimental period ranged from wk 3 prepartum to wk 14 postpartum. The lactating herd was housed in a freestall barn with individual feeding places. From 7 d before expected calving until $5 \mathrm{~d}$ postpartum, animals were fed individually in calving pens with straw bedding. The animals were allocated to 2 experimental groups. The control group was composed of 4 primiparous and 16 multiparous $(2.7 \pm$ 1.1 parities) dairy cows; the treatment group (CLA) included 5 primiparous and 15 multiparous $(2.5 \pm 1.2$ parities) dairy cows.

\section{Feeding Regimen}

Animals received a partial mixed ration (PMR) for ad libitum intake of basic feed with separate and limited intake of concentrates. The PMR was calculated to meet the demands for energy and protein of a cow (650 kg of BW) producing $21 \mathrm{~kg}$ of milk/d with an assumed DMI of $16 \mathrm{~kg}$ of DM/d. The PMR consisted of $33.7 \%$ grass silage, $44.9 \%$ maize silage, $6.4 \%$ hay, and $14.9 \%$ concentrate (DM basis). Partial mixed ration intake was recorded individually by using feed bins that were connected to electronic balances. In addition to the PMR, concentrate (CONC) was offered individually in transponder-access feeding stations by an automatic feeding program (Alpro; DeLaval GmbH, Glinde, Germany). Concentrate was composed of $24.8 \%$ maize, $21.8 \%$ wheat, $20.1 \%$ soybean meal, $15.2 \%$ dried sugar beet pulp with molasses, $14.9 \%$ barley, and $3.2 \%$ vitamin-mineral premix (R-Lactol, Mineralfutter 2 für Rinder, RKW Süd, Würzburg, Germany) including limestone (DM basis). In the first $5 \mathrm{~d}$ of lactation, the cows received $1.2 \mathrm{~kg}$ of $\mathrm{CONC} \mathrm{DM} / \mathrm{d}$. On d 6 postpartum, cows were fed $1.8 \mathrm{~kg}$ of $\mathrm{CONC} \mathrm{DM} / \mathrm{d}$, which 
Table 1. Energy and nutrient concentrations of partial mixed ration (PMR), supplemental concentrate (SUPP), and individually allocated concentrate (CONC)

\begin{tabular}{|c|c|c|c|}
\hline Item & PMR & SUPP & $\mathrm{CONC}$ \\
\hline Energy $^{1}\left(\mathrm{MJ}\right.$ of $\mathrm{NE}_{\mathrm{L}} / \mathrm{kg}$ of $\left.\mathrm{DM}\right)$ & 6.45 & 12.8 & 8.00 \\
\hline Crude fiber $(\mathrm{g} / \mathrm{kg}$ of $\mathrm{DM})$ & 214 & 69 & 67 \\
\hline Crude ash $(\mathrm{g} / \mathrm{kg}$ of $\mathrm{DM})$ & 81 & 49 & 72 \\
\hline Crude fat $(\mathrm{g} / \mathrm{kg}$ of $\mathrm{DM})$ & 32 & 303 & 20 \\
\hline $\mathrm{CP}(\mathrm{g} / \mathrm{kg}$ of $\mathrm{DM})$ & 129 & 140 & 184 \\
\hline Available $\mathrm{CP}^{1}(\mathrm{~g} / \mathrm{kg}$ of $\mathrm{DM})$ & 142 & 151 & 187 \\
\hline
\end{tabular}

${ }^{1}$ Calculated values.

was increased up to $6.2 \mathrm{~kg}$ of $\mathrm{DM} / \mathrm{d}$ in the primiparous cows or $8.0 \mathrm{~kg}$ of $\mathrm{DM} / \mathrm{d}$ in the multiparous cows in the following $35 \mathrm{~d}$. Thereafter, CONC was fed according to individual extra requirements for milk production. Nutrient concentrations and energy content of the feed components are shown in Table 1. Calculations for energy and protein supply followed the recommendations of the German Society of Nutrition Physiology (GfE, 2001).

\section{Administration of Control Fat or CLA}

The dietary fats (control fat or CLA) were supplied via an extra portion of concentrate (supplemental concentrate, SUPP), which consisted (DM basis) of $24.4 \%$ soybean meal, $48.3 \%$ maize, and $27.3 \%$ of rumen-protected fat supplements (control fat or CLA) for both groups. Nutrient concentrations and energy content of SUPP are shown in Table 1. Supplemental concentrate was administered during the whole experimental period from $3 \mathrm{wk}$ prepartum to $14 \mathrm{wk}$ postpartum at a constant amount of $0.63 \mathrm{~kg}$ of $\mathrm{DM} / \mathrm{d}$ for each cow by hand once daily. The cows were separated after milking, fixed in the self-locking feed fence and offered the weighed amount of SUPP. The daily portion of SUPP offered $172 \mathrm{~g}$ of rumen-protected fats per day. The fat of the control group (LactoPlus 2000; Bewital GmbH \& Co. KG, Südlohn, Germany) was free of CLA. The fat of the CLA group (LactoPlus CLA 100; Bewital GmbH \& Co. KG) contained 25 and $22 \mathrm{~g}$ of cis-9,trans-11 CLA and trans-10,cis-12 CLA, respectively, per kilogram, resulting in a daily intake of $4.3 \mathrm{~g}$ of cis-9,trans-11 CLA and $3.8 \mathrm{~g}$ of trans-10,cis-12 CLA per animal and day. With the exception of the 2 CLA isomers, the contents of the major FA in the 2 fats were largely similar, with palmitic and stearic acid being the major FA (Table 2 ). The amount of CLA supplemented was selected in accordance with a recent study in dairy cows (Schwarz et al., 2007). In that study, supplementation of $4 \mathrm{~g}$ of trans-10,cis-12 CLA per animal decreased milk fat by $0.7 \%$ points.

\section{Feed Sampling and Analysis}

All used forages, the PMR, and CONC were sampled once per week, whereas SUPP was sampled once in the experimental period. First, DM content was analyzed by weighing fresh material, drying for $24 \mathrm{~h}$ at $60^{\circ} \mathrm{C}$, and reweighing. Then samples were ground (Brabender GmbH \& Co. KG, Duisburg, Germany; filter width $1.1 \mathrm{~mm}$ ) and PMR samples were combined to 2-wk pools and CONC samples to 4 -wk pools. In these pools, the concentrations of crude nutrients crude ash, crude fiber, and crude fat were determined according to Naumann et al. (2000), whereas CP was analyzed using the Dumas method. The net energy content $\left(\mathrm{MJ}\right.$ of $\mathrm{NE}_{\mathrm{L}}$ ) and the available $\mathrm{CP}$ at the duodenum were calculated according to GfE (2001).

\section{Sample Collection}

Lactating cows were milked twice daily (0500 and $1500 \mathrm{~h}$ ) in a $2 \times 6$ herringbone milking parlor (DeLaval $\mathrm{GmbH}$ ). Milk yields of each cow were recorded automatically and stored in data files. Twice weekly, representative milk samples $(50 \mathrm{~mL})$ from every individual cow were collected by using the sampling device of the milking parlor. One sampling comprised 2 consecutive milking procedures (one evening and the next morning milking). Milk that could not be sold (colostrum, milk from ill cows) was collected in buckets with a scale with which the exact yield could be read.

At wk 1, 5, and 14 of lactation, blood samples of the dammed vena jugularis were taken using sterile 20G cannulas and lithium heparin tubes (Greiner Bio-One GmbH, Kremsmünster, Austria). Blood sampling took place before morning feeding between 0730 and 0900 h. Tubes were kept on ice until subsequent centrifugation $(2,000 \times g$ for $15 \mathrm{~min})$. Plasma was pipetted into 1.5-mL tubes (Greiner Bio-One GmbH, Frickenhausen, Germany) and stored in aliquots at $-20^{\circ} \mathrm{C}$ until analysis.

Table 2. Contents of major FA in the experimental fat supplements $(\mathrm{g} / \mathrm{kg})$

\begin{tabular}{lcc}
\hline FA & Control fat & CLA fat $^{1}$ \\
\hline C14:0 & 17 & 16 \\
C16:0 & 543 & 467 \\
C18:0 & 331 & 259 \\
C18:1 & 7 & 88 \\
C18:2 n-6 & 1 & 27 \\
C18:3 n-3 & 1 & 2 \\
cis-9, trans-11 CLA & - & 25 \\
trans-10, cis-12 CLA & - & 22 \\
C20:0 & 4 & 4 \\
C20:1 & 6 & 6 \\
\hline
\end{tabular}

${ }^{1} \mathrm{CLA}=$ conjugated linoleic acid. 
At wk 1, 5, and 14 of lactation, liver biopsies were taken. Biopsies were conducted before feeding between 0700 and $0900 \mathrm{~h}$. Cows were separated and fixed. After shaving and disinfecting the liver biopsy site on the right side of the cow between the 11th and 12th ribs on a line between the olecranon and the tuber coxae, a local subcutaneous anesthesia with $5 \mathrm{~mL}$ of Isocaine $2 \%$ (procaine hydrochloride/epinephrine; Selectavet Dr. Otto Fischer GmbH, Weyarn/Holzolling, Germany) was performed. Biopsies were taken with sterile $14 \mathrm{G}$ biopsy needles (Dispomed Witt oHG, Gelnhausen, Germany) after introducing an autoclaved cannula as a duct for the needle. About $50 \mathrm{mg}$ of liver tissue were immediately snap frozen in liquid nitrogen. Storage followed at $-80^{\circ} \mathrm{C}$ until further analysis. The biopsy site was treated with wound spray and animals were kept separately until the next day.

\section{Sample Analysis}

Milk samples were analyzed for protein, fat, and lactose by infrared spectrophotometry (MilkoScan FT 6000; Foss Analytical A/S, Hillerød, Denmark) at the laboratory of Milchprüfring Bayern e.V., Wolnzach, Germany. Plasma samples were thawed and analyzed for NEFA, BHBA, TAG, and cholesterol content using commercial available kits [NEFA-HR(2) and Autokit 3-HB, obtained from Wako Chemicals GmbH, Neuss, Germany; Fluitest TG and Fluitest CHOL, obtained from Analyticon Biotechnologies AG, Lichtenfels, Germany]. Lipids from liver biopsy samples were extracted with a mixture of n-hexane and isopropanol $(3: 2, \mathrm{vol} /$ vol; Hara and Radin, 1978). For lipid analyses, aliquots of the lipid extracts were dried and the lipids were dissolved using a 1:1-mixture of chloroform and Triton X-100 (De Hoff et al., 1978). Liver TAG and cholesterol content were measured using enzymatic reagent kits (Fluitest TG and Fluitest CHOL, respectively; Analyticon Biotechnologies AG).

\section{Energy Balance}

Average daily energy balance of every individual cow was calculated. For this purpose, energy intake was calculated from the mean daily intake of PMR, SUPP, and $\mathrm{CONC}$ and the corresponding energy contents (MJ of $\mathrm{NE}_{\mathrm{L}}$ ). Energy requirements for maintenance were calculated using the mean BW of the cows according to GfE (2001). Body weights were automatically recorded daily by electronic scales installed in the feeding stations and used to calculate the weekly mean BW of every individual cow. Energy requirements for milk production were calculated based on weekly means of daily milk yield, milk protein content, and milk fat content according to GfE (2001). Changes in body composition were not considered in energy balance evaluation.

\section{RNA Isolation and Quality Control}

Total RNA was isolated from liver biopsies using Trizol reagent (Invitrogen, Karlsruhe, Germany) according to the manufacturer's protocol. Ribonucleic acid from $15 \mathrm{mg}$ of each sample was isolated within 1 wk after finishing the trial. Isolated RNA was preserved at $-80^{\circ} \mathrm{C}$ until use. Ribonucleic acid concentration and purity were estimated from the optical density at 260 and $280 \mathrm{~nm}$, respectively, using an Infinite $200 \mathrm{M}$ microplate reader and a NanoQuant Plate (both from Tecan Group Ltd., Männedorf, Switzerland). The A260/ A280 ratios were $2.02 \pm 0.05$. The integrity of the total RNA was checked by $1 \%$ agarose gel electrophoresis. Ribonucleic acid was judged as suitable for array hybridization only if the samples exhibited intact bands corresponding to the $18 \mathrm{~S}$ and $28 \mathrm{~S}$ ribosomal RNA subunits. Subsequently, 5 RNA pools each for the control and for the CLA group, were prepared. Each RNA pool comprised RNA from 4 animals.

\section{Microarray Analysis}

For microarray analyses, the RNA pools were sent to the Center of Excellence for Fluorescent Bioanalytics (KFB) at the University of Regensburg (Regensburg, Germany) for hybridization to the Affymetrix GeneChip bovine genome arrays (Affymetrix UK Ltd., High Wycombe, UK). The Affymetrix GeneChip bovine genome array is based on content from UniGene (http://www.ncbi.nlm.nih.gov/unigene) and GenBank (http://www.ncbi.nlm.nih.gov/genbank/) mRNA. It contains 24,027 probe sets representing more than 23,000 transcripts and includes approximately 19,000 UniGene clusters. In brief, total RNA was checked for quality and quantity using an Agilent Bioanalyzer 2100 instrument (Agilent Technologies, Waldbronn, Germany) and total RNA was transcribed to first- and second-strand cDNA. After purification and testing on an Agilent Bioanalyzer 2100, the double-stranded cDNA served as a template for the in vitro transcription reaction for cRNA synthesis. The cRNA was labeled with biotin using the Affymetrix GeneChip labeling kit. After checking the quality and quantity of the labeled cRNA, cRNA was fractionated and hybridized with Affymetrix GeneChips. The GeneChips were washed and stained with the Affymetrix GeneChip Fluidics Station 450. The GeneChips were then scanned with an Affymetrix GeneChip Scanner 3000. All procedures were performed according to Affymetrix protocols (GeneChip expression analysis, technical manual from 


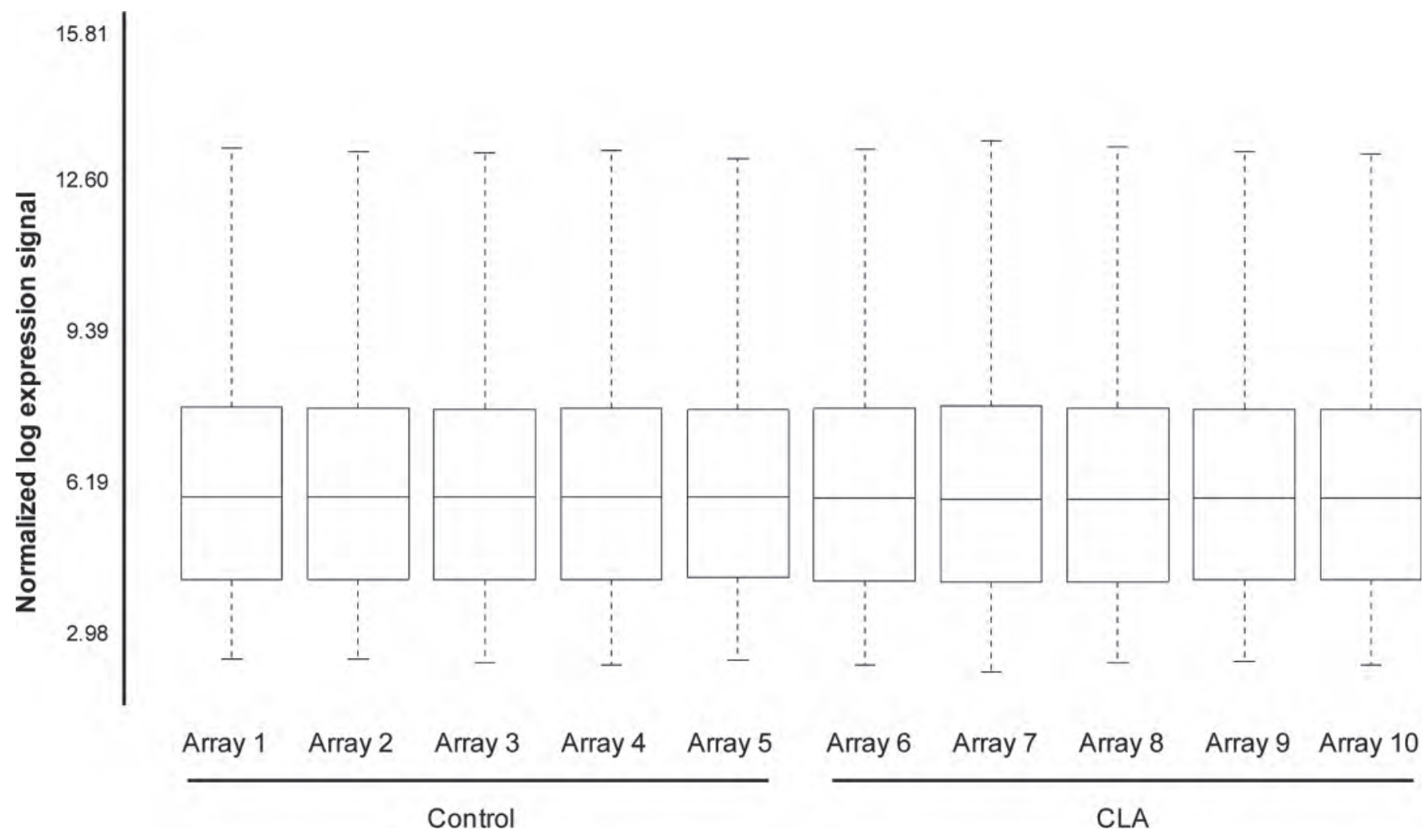

Figure 1. Box plots displaying the average normalized log (base 2) expression signal (y-axis) of all 10 Affymetrix GeneChip (Affymetrix UK Ltd., High Wycombe, UK) bovine genome arrays.

Affymetrix). The quality of hybridization was assessed in all samples following the manufacturer's recommendations. After scanning the arrays, cell intensity files containing a single-intensity value for each probe cell were computed from the image data with the Affymetrix GeneChip Operating Software (GCOS). Probe cell intensity data were further analyzed in the Affymetrix Expression Console 1.1 software using the Affymetrix Microarray Suite Version 5.0 (MAS 5.0) algorithm to create chip files. In the MAS 5.0 algorithm, a global scaling strategy is applied for normalization where the average signal intensity of all probe sets is scaled to a default target signal. The box plots of log (base 2) expression signals of the 10 arrays show that GeneChips were adequately normalized (Figure 1). The fold changes (FC) in gene expression were calculated from the signal $\log$ ratios (SLR) using the following equation: $\mathrm{FC}=2 \mathrm{SLR}$ for $\mathrm{SLR} \geq 0$ and $\mathrm{FC}=(-1) \times 2^{-(\mathrm{SLR})}$ for SLR $<0$. An SLR of zero means no change. The SLR algorithm estimates the magnitude and direction of change of a gene when 2 arrays are compared (CLA versus control). It is calculated by comparing each gene on the CLA array to the corresponding gene on the control array. The log scale used is base 2, making it intuitive to interpret the SLR in terms of multiples of 2. Thus, an SLR of 1 indicates a 2-fold increase of the transcript level, and an SLR of -1.0 indicates a 2-fold decrease. Correspondingly, an FC of 2.0 indicates an increase in the transcript level of $100 \%$, and an FC of -2.0 indicates a decrease of $50 \%$.

\section{Real-Time Quantitative PCR}

Differential expression data of selected genes obtained from Affymetrix GeneChip analysis were validated by real-time quantitative PCR (qPCR). For this purpose, cDNA was synthesized in less than a week after RNA extraction from $1.2 \mu \mathrm{g}$ of total RNA from all individual samples ( $\mathrm{n}=20$ /group) contributing to the RNA pools for microarray analysis using $100 \mathrm{pmol}$ of dT18 primer (Eurofins MWG Operon, Ebersberg, Germany), $1.25 \mu \mathrm{L} 10 \mathrm{mmol} / \mathrm{L}$ of dNTP mix (GeneCraft GmbH, Lüdinghausen, Germany), $5 \mu \mathrm{L}$ of buffer (Fermentas $\mathrm{GmbH}$, St. Leon-Rot, Deutschland), and 60 units of MMuLV Reverse Transcriptase (MBI Fermentas GmbH, St. Leon-Rot, Germany) at $42^{\circ} \mathrm{C}$ for $60 \mathrm{~min}$, and a final inactivating step at $70^{\circ} \mathrm{C}$ for $10 \mathrm{~min}$ in a Biometra Thermal Cycler (Whatman Biometra GmbH, Göttingen, 
Germany). Subsequently, cDNA was stored in aliquots at $-20^{\circ} \mathrm{C}$. For the standard curve, a cDNA pool of all samples was made. Quantitative PCR was performed using $2 \mu \mathrm{L}$ of cDNA combined with $18 \mu \mathrm{L}$ of a mixture composed of $10 \mu \mathrm{L}$ of KAPA SYBR FAST qPCR Universal Master Mix (Peqlab Biotechnologie GmbH, Erlangen, Germany), $0.4 \mu \mathrm{L}$ each of $10 \mu M$ forward and reverse primers, and $7.2 \mu \mathrm{L}$ of DNase/RNase-free water in 0.1-mL tubes (LTF Labortechnik $\mathrm{GmbH} \&$ Co. KG, Wasserburg, Germany). Gene-specific primer pairs obtained from Eurofins MWG Operon were designed using Primer3 (http://frodo.wi.mit.edu/) and BLAST (http://blast.ncbi.nlm.nih.gov/Blast.cgi). Features of primer pairs are listed in Table 3. All primer pairs were designed to have melting temperatures of about $60^{\circ} \mathrm{C}$ and, if possible, both primers of a primer pair were designed to be located in different exons. Quantitative PCR runs were performed using a Rotor-Gene 2000 system (Corbett Research Pty Ltd., Mortlake, Australia), and included all samples and a 5-point relative standard curve plus the nontemplate control (NTC). The qPCR protocol was as follows: $3 \mathrm{~min}$ at $95^{\circ} \mathrm{C}$, followed by 40 cycles of a 2 -step PCR consisting of $5 \mathrm{~s}$ at $95^{\circ} \mathrm{C}$ (denaturation) and $20 \mathrm{~s}$ at $60^{\circ} \mathrm{C}$ (annealing and extension). Subsequently, melting curve analysis was performed from 50 to $95^{\circ} \mathrm{C}$ to verify the presence of a single PCR product. In addition, the amplification of a single product of the expected size was confirmed using $2 \%$ agarose gel electrophoresis stained with GelRed nucleic acid gel stain (Biotium Inc., Hayward, CA). Data on qPCR performance for each genes measured are also shown in Table 3. For determination of relative expression levels relative quantities were calculated using GeNorm normalization factor. To calculate the normalization factor, all cycle threshold $(\mathrm{Ct})$ values were transformed into relative quantification data by using the $2^{-\Delta \mathrm{Ct}}$ equation (Livak and Schmittgen, 2001), and the highest relative quantities for each gene were set to 1. From these values the normalization factor was calculated as the geometric mean of expression data of the 3 most stable out of 6 tested potential reference genes. Reference gene stability across samples was determined by performing GeNorm analysis (Vandesompele et al., 2002), which is based on calculation of a reference genestability measure $M$. Genes with the lowest $M$ values have the most stable expression. After normalization of gene expression data using the calculated GeNorm normalization factor, means and SD were calculated from normalized expression data for samples of the same treatment group. The mean of the control group was set to 1 and mean and SD of the CLA group was scaled proportionally. After normalization, means and SD were calculated from normalized expression data for samples of the same treatment group. Relative expression ratios of the CLA group are expressed as fold changes compared with the control group.

\section{Statistics}

Data are presented as means \pm standard errors of the means. The individual cow serves as experimental unit. Statistical analysis of performance and metabolic data was performed using the MIXED procedure of SAS version 9.2 (SAS Institute Inc., Cary, NC). For each performance parameter, the model included lactation week, treatment group, parity of the cow (primiparous and multiparous), and the lactation week $\times$ treatment group interaction. The repeated subject was the individual cow. The significances of differences between the groups over time were analyzed using the Bonferroni $t$-test. Differences were regarded as significant at $P<$ 0.05 .

\section{RESULTS}

\section{Feed Intake, Energy Balance, Milk Yield, and Milk Composition}

As expected, the DMI of the cows rose from wk 1 to 14. Dry matter intake was not significantly different between the CLA group and the control group, but a tendency $(P=0.075)$ existed toward an increase in DMI $(+0.4 \mathrm{~kg})$ in the cows supplemented with CLA during the period from wk 1 to 14 (Table 4). Daily milk yield during the whole period was higher in the CLA group than in the control group $(P<0.001)$. In wk 1 of lactation, milk fat was not different between the 2 groups of cows. However, during the whole period, milk fat and daily amount of milk fat were 0.6 percentage points and $0.17 \mathrm{~kg}$, respectively, lower in the CLA group than in the control group $(P<0.001$; Table 4). For milk protein concentration, an interaction between treatment and time $(P=0.028)$ was observed: in wk 1 and 5 , no difference in milk protein content was observed; in wk 14, milk protein content was decreased in the CLA group compared with the control group $(P$ $<0.05)$. During the whole period, milk protein content was decreased by 0.15 percentage points in the CLA group $(P<0.001)$, whereas daily milk protein yield was not different between the 2 groups of cows (Table 4 ). The concentration of lactose in the milk was not different between the 2 groups of cows. Due to the decreased milk fat content, amounts of FCM and ECM were lower in the CLA group than in the control group $(P=0.002$ and $P=0.005$, respectively; Table 4 ). The energy bal- 
Table 3. Characteristics and performance data of the primers used for quantitative PCR analysis and reference gene-stability measure $M$

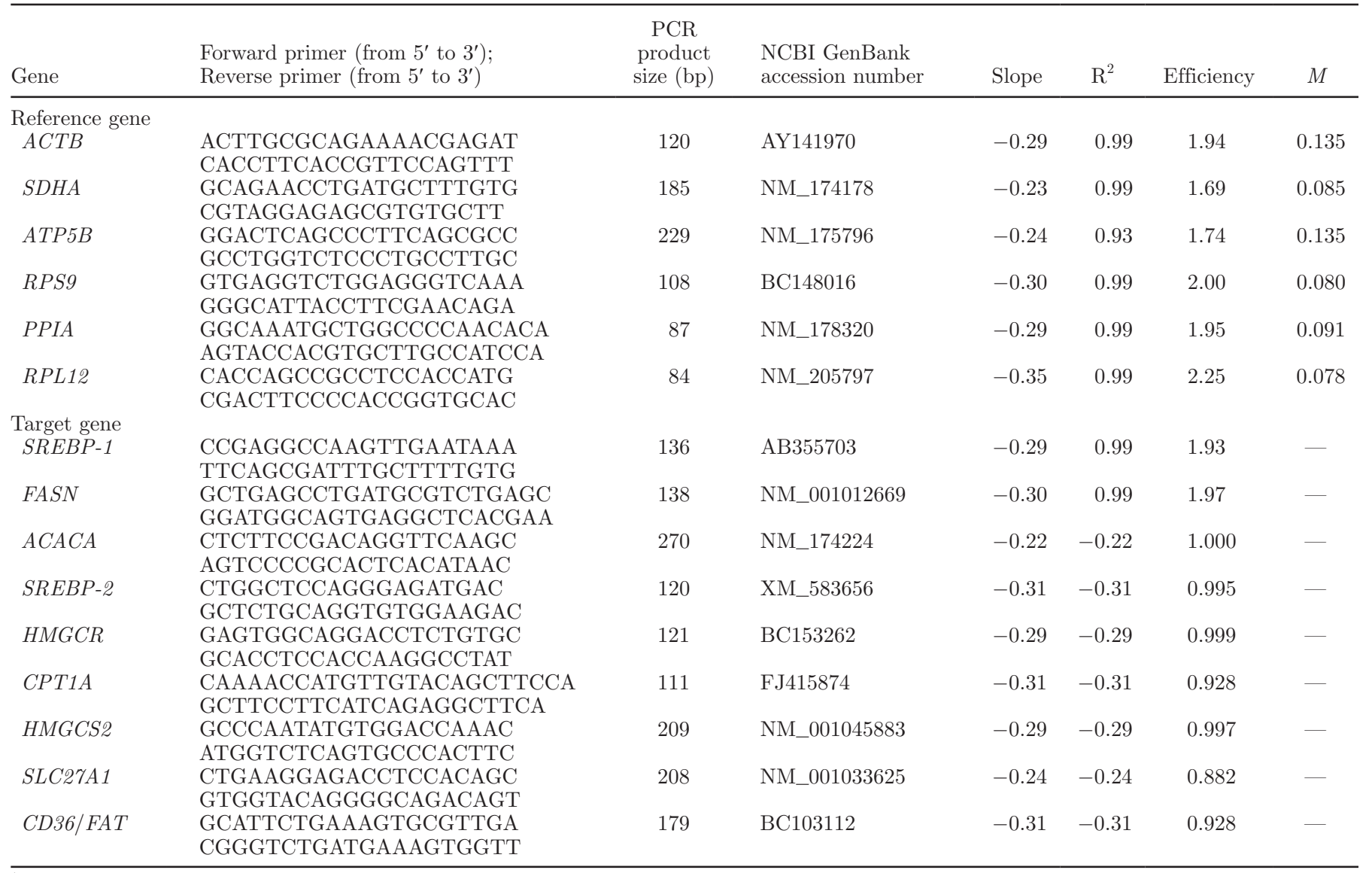

${ }^{1} A C T B=\operatorname{actin} \beta ; S D H A=$ succinate dehydrogenase complex, subunit A, flavoprotein $(\mathrm{Fp}) ; A T P 5 B=$ ATP synthase, $\mathrm{H}^{+}$transporting, mitochondrial F1 complex, $\beta$ polypeptide; $R P S 9=$ ribosomal protein $\mathrm{S} 9 ;$ PPIA = peptidylprolyl isomerase A (cyclophilin A); RPL12 = ribosomal protein L12; SREBP-1 = sterol regulatory element-binding protein $1 ; F A S N=$ FA synthase; $A C A C A=$ acetyl-CoA carboxylase $\alpha ; S R E B P-2=$ sterol regulatory element-binding protein $2 ; H M G C R=3$-hydroxy-3-methylglutaryl-CoA reductase; $C P T 1 A=$ carnitine palmitoyltransferase $1 \mathrm{~A}$ (liver); HMGCS2 = 3-hydroxy-3-methylglutaryl-CoA synthase 2 (mitochondrial); SLC27A1 = solute carrier family 27 (FA transporter), member 1; $C D 36 / F A T=$ CD36/FA translocase; NCBI = National Center for Biotechnology Information

ance during the whole period was improved in the CLA group compared with the control group $(P=0.024)$.

\section{Concentrations of NEFA and BHBA in Plasma}

In wk 1, plasma concentration of NEFA in the CLA group was lower than in the control group $(P<0.05$; Table 5). In wk 5 and 14, no difference was observed in plasma NEFA concentration between both groups of cows. Plasma BHBA concentration was not different between the 2 groups of cows during the whole period (Table 5).

\section{Concentrations of TAG and Cholesterol in Liver and Plasma}

Hepatic TAG showed the expected dependence on lactation week, being highest in wk 5 of lactation. Conjugated linoleic acid supplementation, however, did not change hepatic TAG concentration (Table 5). Hepatic cholesterol concentration was also not different between the 2 groups of cows. Plasma TAG and cholesterol concentrations at wk 5 were not different between the 2 groups of cows (Table 5).

\section{Expression of Genes Involved in Hepatic FA Uptake and Intracellular FA Transport}

To assess the effect of CLA on hepatic FA uptake and intracellular transport, we considered the expression of a total of 6 genes encoding FA transporters (SLC27A1, SLC27A2, SLC27A4, SLC27A5, SLC27A6, and $C D 36 / F A T)$ and 7 genes encoding FA-binding proteins (FABP1 to $\%$; Table 6 ). The expression of these genes was not differentially regulated between the CLA group and the control group, indicating that CLA did not affect FA uptake into the liver and FA binding and transport in the liver. This indication is supported by 
Table 4. Effect of conjugated linoleic acid (CLA) on performance parameters in Holstein cows at wk 1, 5, and 14 of lactation and during the whole period (wk 1 to 14)

\begin{tabular}{|c|c|c|c|c|c|c|c|c|c|c|c|c|}
\hline \multirow[b]{2}{*}{ Variable } & \multicolumn{2}{|c|}{ wk 1} & \multicolumn{2}{|c|}{ wk 5} & \multicolumn{2}{|c|}{ wk 14} & \multicolumn{2}{|c|}{ wk 1 to 14} & \multirow[b]{2}{*}{ SEM } & \multicolumn{3}{|c|}{$P$-value } \\
\hline & Control & CLA & Control & CLA & Control & CLA & Control & CLA & & CLA & Time & CLA $\times$ time \\
\hline DMI $(\mathrm{kg} / \mathrm{d})$ & 13.4 & 16.0 & 18.4 & 19.1 & 20.4 & 21.3 & 20.2 & 20.6 & 0.17 & 0.075 & $<0.0001$ & 0.997 \\
\hline Milk yield $(\mathrm{kg} / \mathrm{d})$ & 28.6 & 28.5 & 37.5 & 38.6 & $32.0^{\mathrm{b}}$ & $35.6^{\mathrm{a}}$ & $35.6^{\mathrm{b}}$ & $37.1^{\mathrm{a}}$ & 0.23 & $<0.0001$ & $<0.0001$ & 0.072 \\
\hline $\mathrm{FCM}^{1}(\mathrm{~kg} / \mathrm{d})$ & 39.2 & 38.8 & 40.9 & 38.6 & 33.0 & 31.9 & $38.2^{\mathrm{a}}$ & $36.3^{\mathrm{b}}$ & 0.28 & 0.002 & $<0.0001$ & 0.968 \\
\hline $\mathrm{ECM}^{2}(\mathrm{~kg} / \mathrm{d})$ & 38.3 & 37.8 & 38.9 & 37.1 & 32.3 & 31.6 & $36.9^{\mathrm{a}}$ & $35.4^{\mathrm{b}}$ & 0.25 & 0.005 & $<0.0001$ & 0.960 \\
\hline Milk fat (\%) & 6.40 & 6.21 & $4.51^{\mathrm{a}}$ & $3.85^{\mathrm{b}}$ & $4.11^{\mathrm{a}}$ & $3.19^{\mathrm{b}}$ & $4.40^{\mathrm{a}}$ & $3.81^{\mathrm{b}}$ & 0.05 & $<0.0001$ & $<0.0001$ & 0.743 \\
\hline Milk fat yield $(\mathrm{kg} / \mathrm{d})$ & 1.78 & 1.75 & $1.68^{\mathrm{a}}$ & $1.47^{\mathrm{b}}$ & 1.31 & 1.12 & $1.56^{\mathrm{a}}$ & $1.39^{\mathrm{b}}$ & 0.02 & $<0.0001$ & $<0.0001$ & 0.991 \\
\hline Milk protein $(\%)$ & 4.09 & 4.15 & 2.85 & 2.76 & $3.13^{\mathrm{a}}$ & $2.87^{\mathrm{b}}$ & $3.11^{\mathrm{a}}$ & $2.96^{\mathrm{b}}$ & 0.02 & $<0.0001$ & $<0.0001$ & 0.028 \\
\hline Milk protein yield (kg/d) & 1.22 & 1.14 & 1.06 & 1.05 & 1.00 & 1.00 & 1.10 & 1.08 & 0.01 & 0.193 & 0.0002 & 0.842 \\
\hline Milk lactose (\%) & 4.38 & 4.36 & 4.76 & 4.80 & 4.75 & 4.75 & 4.75 & 4.74 & 0.01 & 0.356 & $<0.0001$ & 0.984 \\
\hline Energy balance $^{3}\left(\mathrm{MJ}\right.$ of $\mathrm{NE}_{\mathrm{L}} / \mathrm{d}$ ) & -64.9 & -55.4 & $-30.4^{\mathrm{b}}$ & $-20.7^{\mathrm{a}}$ & $3.9^{\mathrm{b}}$ & $5.9^{\mathrm{a}}$ & $-10.9^{\mathrm{b}}$ & $-5.59^{\mathrm{a}}$ & 1.40 & 0.024 & $<0.0001$ & 0.440 \\
\hline
\end{tabular}

${ }^{\mathrm{a}, \mathrm{b}}$ Means within rows within the same lactation week with different superscripts differ $(P<0.05)$.

${ }^{1}$ Corrected for $4 \%$ milk fat content.

${ }^{2}$ Corrected for $4 \%$ milk fat content and $3.4 \%$ milk protein content.

${ }^{3}$ Calculated value.

Table 5. Effect of conjugated linoleic acid (CLA) on metabolic parameters in Holstein cows at wk 1, 5, and 14 of lactation and in average of wk 1, 5, and 14

\begin{tabular}{|c|c|c|c|c|c|c|c|c|c|c|c|c|}
\hline \multirow[b]{2}{*}{ Variable } & \multicolumn{2}{|c|}{ wk 1} & \multicolumn{2}{|c|}{ wk 5} & \multicolumn{2}{|c|}{ wk 14} & \multicolumn{2}{|c|}{ wk $1,5,14$} & \multirow[b]{2}{*}{ SEM } & \multicolumn{3}{|c|}{$P$-value } \\
\hline & Control & CLA & Control & CLA & Control & CLA & Control & CLA & & CLA & Time & CLA $\times$ time \\
\hline Plasma NEFA $(\mu \mathrm{mol} / \mathrm{L})$ & $867^{\mathrm{a}}$ & $731^{\mathrm{b}}$ & 283 & 284 & 171 & 148 & 440 & 388 & 24.4 & 0.535 & $<0.0001$ & 0.014 \\
\hline Plasma BHBA $(\mu \mathrm{mol} / \mathrm{L})$ & 707 & 747 & 724 & 723 & 521 & 531 & 651 & 667 & 14.9 & 0.317 & $<0.0001$ & 0.910 \\
\hline Plasma $\mathrm{TAG}^{1,2}(\mathrm{mmol} / \mathrm{L})$ & - & - & 0.13 & 0.14 & - & - & - & - & 0.003 & 0.175 & - & - \\
\hline Plasma cholesterol $^{2}(\mathrm{mmol} / \mathrm{L})$ & - & - & 4.55 & 4.52 & - & - & - & - & 2.91 & 0.08 & - & - \\
\hline Liver TAG ( $\mu \mathrm{mol} / \mathrm{g}$ of liver $)$ & 25.1 & 20.0 & 59.7 & 54.9 & 3.4 & 3.4 & 28.2 & 23.7 & 2.41 & 0.610 & $<0.0001$ & 0.841 \\
\hline Liver cholesterol $(\mu \mathrm{mol} / \mathrm{g}$ of liver $)$ & 15.4 & 13.9 & 12.1 & 10.9 & 6.7 & 7.1 & 11.0 & 10.0 & 0.03 & 0.375 & $<0.0001$ & 0.094 \\
\hline
\end{tabular}

${ }^{\mathrm{a}, \mathrm{b}}$ Means within the same lactation week with different superscripts differ $(P<0.05)$.

${ }^{1} \mathrm{TAG}=$ triacylglycerol

${ }^{2}$ Plasma TAG and plasma cholesterol were determined only at wk 5. 
Table 6. Effect of conjugated linoleic acid (CLA) on the expression of genes involved in hepatic FA uptake, intracellular FA transport, mitochondrial and peroxisomal $\beta$-oxidation, carnitine metabolism, and ketogenesis in Holstein cows at wk 5

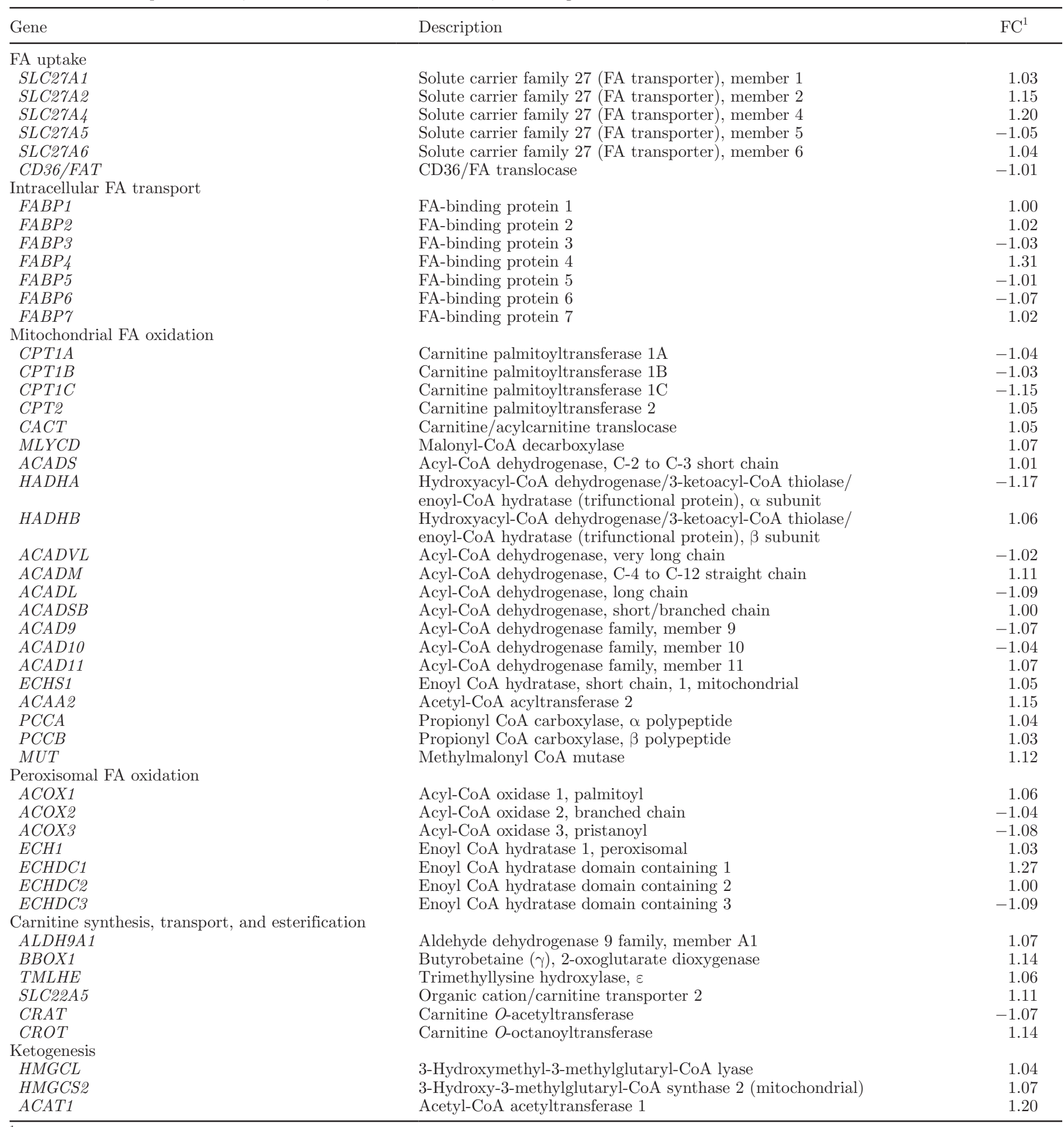

${ }^{1}$ Fold change in the CLA group versus the control group. For example, an FC of 2.0 indicates an increase in the transcript level of $100 \%$, and an FC of -2.0 indicates a decrease of $50 \%$.

qPCR analysis of CD36 and FATP1, 2 important FA transporters, which revealed no difference in relative mRNA concentrations of these genes (CLA group vs. control group: $C D 36$ : $0.73 \pm 0.64$ vs. $1.00 \pm 0.69$; FATP1: $0.85 \pm 0.51$ vs. $1.00 \pm 0.57 ; P>0.05$ for both genes). 


\section{Expression of Genes Involved in Mitochondrial and Peroxisomal $\beta$-Oxidation of FA, Carnitine Metabolism, and Ketogenesis}

To assess the effect of CLA on hepatic mitochondrial and peroxisomal $\beta$-oxidation, we considered the expression of 21 and 7 genes, respectively, involved in those pathways (Table 6). None of the genes considered was differentially regulated in the CLA group compared with the control group. Carnitine is required for the transport of acyl-CoA into the mitochondrion and, thus, is an essential cofactor in $\beta$-oxidation. To assess whether CLA influenced carnitine metabolism, we determined the expression of 5 genes involved in synthesis (ALDH9A1, BBOX1, and TMLHE), transport (SLC22A5), and esterification (CRAT and CROT) of carnitine (Table 6). The expression of all of these genes was not different between the 2 groups of cows. Moreover, expression of 3 genes involved in ketogenesis was not different between cows supplemented with CLA and cows of the control group. The consideration of all of the genes involved in $\beta$-oxidation, carnitine metabolism, and ketogenesis indicates that hepatic mitochondrial and peroxisomal $\beta$-oxidation, metabolism of carnitine, and ketogenesis were not influenced by supplementation of CLA. This indication was confirmed by determining relative mRNA concentrations of CPT1A and HMGCS2, key enzymes of mitochondrial $\beta$-oxidation and ketogenesis, respectively, by qPCR (CLA group vs. control group: CPT1A: $0.93 \pm 0.68$ vs. $1.00 \pm 0.56 ; H M G C S 2: 0.84 \pm$ 0.41 vs. $1.00 \pm 0.57 ; P>0.05$ for both genes).

\section{Expression of Genes Involved in Lipid Synthesis}

To assess the effect of CLA on lipid synthesis, we considered the expression of 7 genes involved in FA synthesis, 4 genes involved in TAG synthesis, 5 genes involved in the synthesis of unsaturated FA (desaturases), 5 genes involved in elongation of FA (elongases), and 17 genes involved in cholesterol synthesis (Table 7 ). None of these genes was differentially regulated in the CLA group in comparison to the control group, indicating that CLA had no influence on hepatic lipid synthesis. This indication was confirmed by determining relative mRNA concentrations of $A C C$ and FASN (2 enzymes of FA synthesis), $H M G C R$ (the key enzyme of cholesterol synthesis), and SREBP-1 and SREBP-2 (2 transcription factors controlling the transcription of genes involved in lipogenesis and cholesterol synthesis). Relative mRNA concentrations of these genes in the CLA group versus control group were as follows: $A C C$ : $1.25 \pm 0.66$ vs. $1.00 \pm 0.56 ; F A S N$ : $0.73 \pm 0.64$ vs. $1.00 \pm 0.69 ;$ HMGCR: $1.04 \pm 0.62$ vs. $1.00 \pm 0.51$; SREBP-1: $0.89 \pm 0.59$ vs. $1.00 \pm 0.52 ; S R E B P-2: 0.90$ \pm 0.57 vs. $1.00 \pm 0.52$ ( $P>0.05$ for all genes $)$.

\section{Expression of Genes Involved in Lipoprotein Uptake and Metabolism}

To assess the effect of CLA on hepatic lipoprotein metabolism, we considered the expression of 2 genes involved in lipoprotein uptake ( $V L D L R$ and $L D L R$ ), 6 genes involved in lipoprotein metabolism, and 12 genes involved in lipoprotein secretion (Table 7). All of these genes were not differentially regulated between cows of the CLA group and cows of the control group, indicating that uptake, metabolism, as well as assembly and secretion of lipoproteins were not affected by supplementation of CLA.

\section{DISCUSSION}

The present study aimed to investigate the influence of feeding rumen-protected CLA on liver lipid metabolism in dairy cows. For this purpose, dairy cows received a rumen-protected CLA mixture supplying 3.8 $\mathrm{g}$ of trans-10,cis-12 CLA per day as milk fat-depressing compound from late pregnancy to wk 14 of lactation. The finding that such a moderate amount of trans10, cis-12 CLA caused a considerable decrease in milk fat of around $0.6 \%$ points from wk 1 to 14 of lactation agrees with several other studies (Giesy et al., 2002; Piperova et al., 2004; Odens et al., 2007; Schwarz et al., 2007), confirming that trans-10,cis-12 CLA is highly efficient in decreasing milk fat. The finding that milk fat was not decreased in wk 1 of lactation by CLA agrees with several other studies that used moderate doses of CLA (Bernal-Santos et al., 2003; Selberg et al., 2004; Kay et al., 2006; Pappritz et al., 2011). Kay et al. (2006) hypothesized that the lack of effect in the first week of lactation could be due to a decreased uptake of CLA into the mammary gland immediately postpartum. During the transition period, plasma NEFA concentrations are very high, and these NEFA deriving from adipose tissue might compete with CLA for their uptake into mammary gland epithelial cells.

In the present study, CLA supplementation tended to increase DMI $(P=0.075)$ and increased milk yield but lowered energy output via milk due to the decreased milk fat content, resulting in an improved energy balance during lactation. The finding of an improved energy balance agrees with some other studies and confirms that supplementation of CLA may be a dietary strategy to prevent health problems associated with NEB in dairy cows (Kay et al., 2006; Odens et al., 2007; Schwarz et al., 2007). It has been shown that plasma NEFA concentration is a reliable index of the magnitude of adipose fat mobilization (Bauman et al., 1988). Thus, an improvement of NEB is expected to lower plasma NEFA concentration. Indeed, CLA- 
Table 7. Effect of conjugated linoleic acid (CLA) on the expression of genes involved in hepatic FA synthesis, triacylglycerol (TAG) synthesis, synthesis of unsaturated FA, elongation of FA, cholesterol synthesis, lipoprotein uptake, lipoprotein metabolism, and lipoprotein secretion in Holstein cows at wk 5

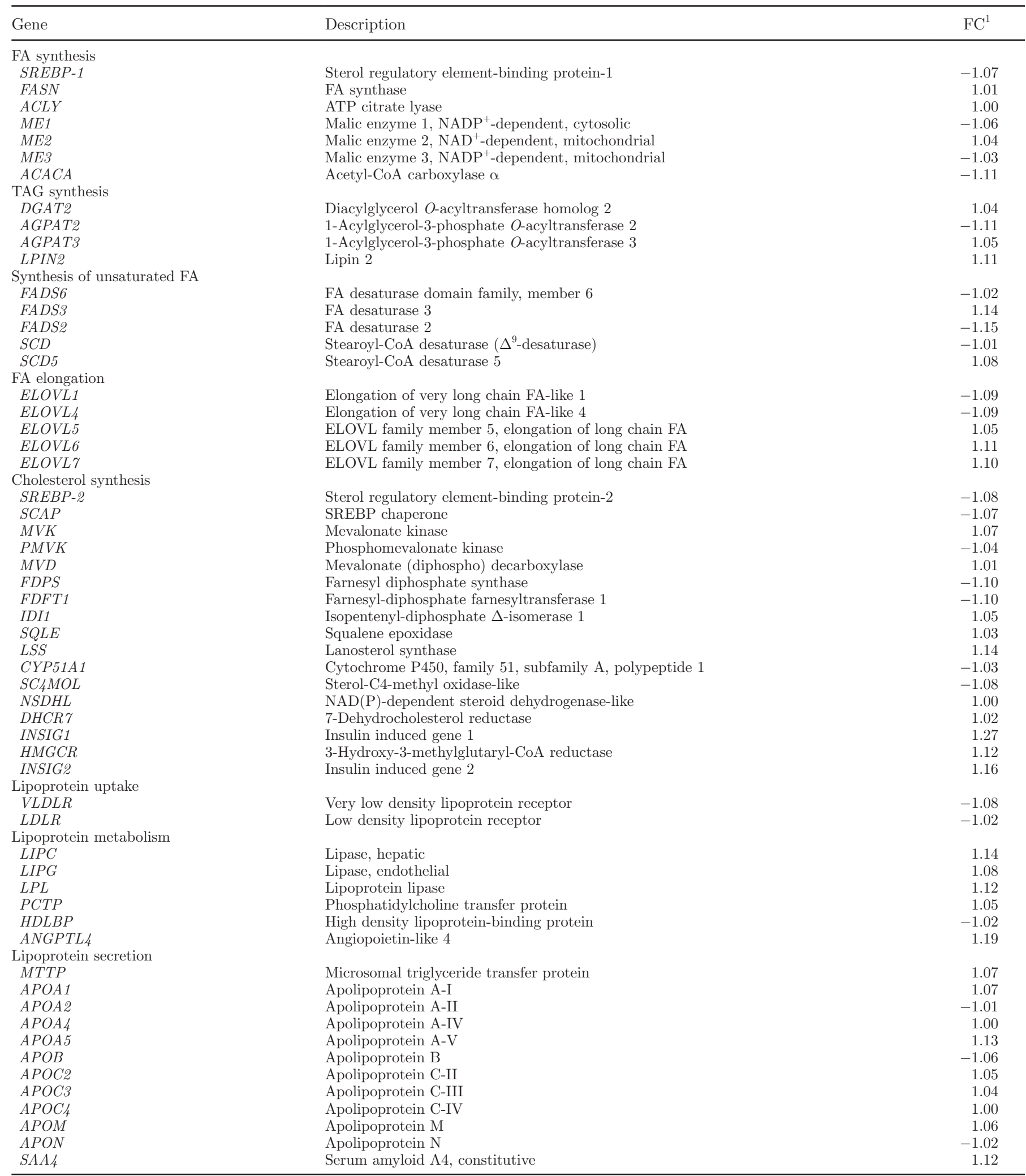

${ }^{1}$ Fold change in the CLA group versus the control group. For example, an FC of 2.0 indicates an increase in the transcript level of $100 \%$, and an $\mathrm{FC}$ of -2.0 indicates a decrease of $50 \%$. 
supplemented cows exerted a decreased plasma NEFA concentration in wk 1 of lactation, the time point of the strongest improvement of NEB by CLA. In contrast, NEFA concentrations at wk 5 and 14 were not different between both groups of cows, although energy balance was also improved at those time points. We assume that the differences in energy balance at those time points were not great enough to cause a significant alteration in plasma NEFA concentration. Notably, our study disagrees with a study of Selberg et al. (2004) who found an increased plasma NEFA concentration in cows supplemented with CLA in wk 1 of lactation. Their finding indicated that CLA supplementation transiently enhances lipolysis shortly after calving. The observation of unchanged plasma NEFA concentrations in wk 5 and 14 of lactation agrees with most other studies showing that CLA does not influence plasma NEFA concentration (Perfield et al., 2002; Bernal-Santos et al., 2003; Castañeda-Gutiérrez et al., 2005; Pappritz et al., 2011).

The primary aim of this study was to elucidate whether CLA could exert adverse effects on hepatic lipid metabolism. Therefore, we determined hepatic concentrations of TAG and cholesterol in liver biopsy samples and performed a GeneChip analysis in samples obtained at wk 5 of lactation, representing the phase in which hepatic lipid concentrations are highest during lactation. Although GeneChip analysis generates rather semiquantitative data, the use of this technique has the great advantage that a great number of genes involved in several pathways of lipid metabolism can be detected simultaneously in a small sample amount. This is especially important when using small biopsy samples, such as in the present study. Nevertheless, we also determined mRNA concentrations of key enzymes of the relevant pathways by means of qPCR to confirm the validity of GeneChip data.

Fatty acid uptake, FA binding, FA oxidation, ketogenesis, as well as carnitine synthesis and uptake are pathways that are mainly controlled by peroxisome proliferator-activated receptor $(\boldsymbol{P P A R}) \alpha$, a transcription factor that acts as an important regulator of lipid metabolism and energy homeostasis (Desvergne and Wahli, 1999). It has been found that CLA are able to bind to and activate PPAR $\alpha$ (Moya-Camarena et al., 1999a). In addition, several feeding studies in rodents have shown that feeding of CLA causes an activation of PPAR $\alpha$ in vivo and, thus, stimulates pathways controlled by PPAR $\alpha$ such as mitochondrial and peroxisomal $\beta$-oxidation (Belury et al., 1996; MoyaCamarena et al., 1999b; Ringseis et al., 2004). The finding that mRNA concentrations of many genes directly controlled by $P P A R \alpha$, such as $A C O, C P T 1 A$, or $H M G C S 2$, were unchanged in cows supplemented with
CLA clearly indicates that CLA supplementation did not cause an activation of PPAR $\alpha$ in the liver. It is well known that NEFA deriving from adipose tissue, taken up into the liver, are acting as endogenous ligands of PPAR $\alpha$. Therefore, increased plasma concentrations of NEFA cause an activation of PPAR $\alpha$ (Mandard et al., 2004). Thus, the finding that plasma NEFA concentrations were not influenced by CLA is in line with the observation that no activation of PPAR $\alpha$ occurred in the cows supplemented with CLA. The observation that expression of HMGCS2, the key enzyme of hepatic ketogenesis, was not altered is in agreement with the finding of an unchanged concentration of plasma BHBA. Several other studies in dairy cows also observed that supplementation of CLA does not change plasma BHBA concentration in dairy cows (Perfield et al., 2002; Bernal-Santos et al., 2003; Selberg et al., 2004; Pappritz et al., 2011).

Synthesis of FA (including FA elongation and desaturation) and cholesterol is mainly controlled by $S R E B P-1 c$ and SREBP-2, respectively. In the liver of mice, supplementation of CLA caused an activation of $S R E B P-1 c$ associated with an upregulation of several enzymes involved in de novo synthesis of FA and TAG (Clément et al., 2002). In the present study, genes involved in FA and cholesterol synthesis were not different in their expression between CLA and control cows. This indicates that both $S R E B P-1 c$ and SREBP-2 were not activated by supplementation of CLA in dairy cows.

Hepatic TAG concentration is the result of various pathways of lipid metabolism, including uptake of FA from plasma, oxidation of FA, de novo synthesis of FA, and secretion of TAG via VLDL (Katoh, 2002). Early lactation is a critical phase with respect to hepatic lipid metabolism as the amount of FA taken up from plasma into the liver normally exceeds the capacity of FA oxidation and secretion of TAG via VLDL. For this reason, hepatic TAG concentration in dairy cows is normally highest in early lactation. Accordingly, hepatic TAG concentration in the present study was highest in wk 5 and decreased until wk 14. The finding that genes involved in uptake, oxidation, and de novo synthesis of FA as well as secretion of TAG via VLDL were not differentially regulated by CLA matches with the unchanged hepatic TAG concentration in cows supplemented with CLA compared with control cows. The finding that CLA does not influence hepatic TAG concentration in dairy cows is in agreement with 3 other studies (Bernal-Santos et al., 2003; Selberg et al., 2004; Castañeda-Gutiérrez et al., 2005). Our study, moreover, shows that CLA does not influence hepatic cholesterol concentration. This observation is in line with the findings of unchanged expression of genes in- 
volved in cholesterol synthesis, cholesterol uptake via LDL, and cholesterol secretion via VLDL.

Concentrations of lipids in plasma are the result of 1) assembly of lipoproteins in tissues and secretion into the blood, 2) decomposition of circulating lipoproteins, and 3) uptake of lipoproteins into tissues by receptors. The GeneChip analysis showed that CLA did not alter the expression of genes involved in hepatic uptake of lipoproteins such as VLDL or LDL receptor, genes involved in decomposition of lipoproteins such as hepatic lipase or lipoprotein lipase, or genes involved in hepatic assembly of VLDL such as microsomal triglyceride transfer protein $(M T T P)$ and several apolipoproteins. According to these observations, indicating that CLA had no effect on hepatic lipoprotein metabolism, it was not unexpected that plasma concentrations of TAG and cholesterol were not altered in cows supplemented with CLA.

Notably, the effects observed in this study are similar to those of a recent study performed with growing beef cattle. In that study, daily supplementation of $5 \mathrm{~g}$ of rumen-protected trans-10,cis-12 CLA in cattle also had less effect on expression of genes involved in hepatic lipid metabolism and did not change plasma and liver concentrations of TAG and cholesterol (Shibani et al., 2011). However, the findings of the present study strongly differ from those observed in rodents. In mice, trans-10,cis-12 CLA caused the development of severe fatty liver. The differences between the 2 species can be either due to species specificity of the effects or to differences in supplementation levels. In mice, development of fatty liver was observed in studies using diets with 0.25 to $1 \%$ trans-10, cis-12 CLA (Belury and Kempa-Steczko, 1997; Tsuboyama-Kasaoka et al., 2000; Clément et al., 2002). In contrast, the daily supplementation of $3.8 \mathrm{~g}$ of trans-10, cis-12 CLA per day in dairy cows was equivalent to a concentration of only $0.02 \%$ of total DMI.

\section{CONCLUSIONS}

The present study confirms previous studies in showing that supplementation of a rumen-protected CLA mixture is an effective way to lower milk fat concentration and to improve energy balance during early lactation in dairy cows. The study moreover shows, using a GeneChip as a tool to detect the expression of a broad range of genes involved in various pathways, that a dose of CLA effective for milk fat depression does not influence the metabolism of lipids (uptake, oxidation, and synthesis of FA, including synthesis of carnitine; uptake, synthesis, and secretion of cholesterol; metabolism and secretion of lipoproteins; or ketogenesis) and hepatic and plasma concentrations of TAG and cholesterol.
Thus, based on these data, adverse effects of CLA - at a level sufficient for depression of milk fat-on hepatic lipid metabolism in dairy cows can be excluded.

\section{ACKNOWLEDGMENTS}

G. Schlegel was supported by H. Wilhelm Schaumann Stiftung (Hamburg, Germany).

\section{REFERENCES}

Akter, S. H., S. Häussler, S. Dänicke, U. Müller, D. von Soosten, J. Rehage, and H. Sauerwein. 2011. Physiological and conjugated linoleic acid-induced changes of adipocyte size in different fat depots of dairy cows during early lactation. J. Dairy Sci. 94:2871-2882.

Bauman, D. E., and C. L. Davis. 1974. Biosynthesis of milk fat. Pages 31-75 in Lactation: A Comprehensive Treatise. Vol. 2. B. L. Larson and V. R. Smith, ed. Academic Press, New York, NY.

Bauman, D. E., K. J. Harvatine, and A. L. Lock. 2011. Nutrigenomics, rumen-derived bioactive fatty acids, and the regulation of synthesis. Annu. Rev. Nutr. 31:299-319. http://dx.doi.org/10.1146/ annurev.nutr.012809.104648.

Bauman, D. E., C. J. Peel, W. D. Steinhour, P. J. Reynolds, H. F. Tyrrell, A. C. G. Brown, and G. L. Haaland. 1988. Effect of bovine somatotropin on metabolism of lactating dairy cows: Influence on rates of irreversible loss and oxidation of glucose and nonesterified fatty acids. J. Nutr. 118:1031-1040.

Bauman, D. E., J. W. Perfield II, K. J. Harvatine, and L. H. Baumgard. 2008. Regulation of fat synthesis by conjugated linoleic acid: Lactation and the ruminant model. J. Nutr. 138:403-409.

Baumgard, L. H., B. A. Corl, D. A. Dwyer, and D. E. Bauman. 2002a. Effects of conjugated linoleic acids (CLA) on tissue response to homeostatic signals and plasma variables associated with lipid metabolism in lactating dairy cows. J. Anim. Sci. 80:1285-1293.

Baumgard, L. H., E. Matitashvili, B. A. Corl, D. A. Dwyer, and D. E. Bauman. 2002b. trans-10, cis-12 conjugated linoleic acid decreases lipogenic rates and expression of genes involved in milk lipid synthesis in dairy cows. J. Dairy Sci. 85:2155-2163.

Belury, M. A., and A. Kempa-Steczko. 1997. Conjugated linoleic acid modulates hepatic lipid composition in mice. Lipids 32:199-204.

Belury, M. A., K. P. Nickel, C. E. Bird, and Y. Wu. 1996. Dietary conjugated linoleic acid modulation of phorbol ester skin tumor promotion. Nutr. Cancer 26:149-157.

Bernal-Santos, G., J. W. Perfield II, D. M. Barbano, D. E. Bauman, and T. R. Overton. 2003. Production responses of dairy cows to dietary supplementation with conjugated linoleic acid (CLA) during the transition period and early lactation. J. Dairy Sci. $86: 3218-3228$

Castañeda-Gutiérrez, E., T. R. Overton, W. R. Butler, and D. E. Bauman. 2005. Dietary supplements of two doses of calcium salts of conjugated linoleic acid during the transition period and early lactation. J. Dairy Sci. 88:1078-1089.

Clément, L., H. Poirier, I. Niot, V. Bocher, M. Guerre-Millo, S. Krief, B. Staels, and P. Besnard. 2002. Dietary trans-10,cis-12 conjugated linoleic acid induces hyperinsulinemia and fatty liver in the mouse. J. Lipid Res. 43:1400-1409.

De Hoff, J. L., L. M. Davidson, and D. Kritchevsky. 1978. An enzymatic assay for determining free and total cholesterol in tissue. Clin. Chem. 24:433-435.

Desvergne, B., and W. Wahli. 1999. Peroxisome proliferator-activated receptors: Nuclear control of metabolism. Endocr. Rev. 20:649 688

Drackley, J. K. 1999. Biology of dairy cows during the transition period: The final frontier? J. Dairy Sci. 82:2259-2273.

GfE (German Society of Nutrition Physiology). 2001. Empfehlungen zur Energie- und Nährstoffversorgung der Milchkühe und Aufzuchtrinder. DLG-Verlag, Frankfurt/Main, Germany. 
Giesy, J. G., M. A. McGuire, B. Shafii, and T. W. Hanson. 2002 Effect of dose of calcium salts of conjugated linoleic acid (CLA) on percentage and fatty acid content of milk fat in midlactation Holstein cows. J. Dairy Sci. 85:2023-2029.

Giudetti, A. M., A. C. Beynen, A. G. Lemmens, G. V. Gnoni, and M. J. Geelen. 2005. Hepatic lipid and carbohydrate metabolism in rats fed a commercial mixture of conjugated linoleic acids (Clarinol G-80). Eur. J. Nutr. 44:33-39.

Ha, Y. L., N. K. Grimm, and M. W. Pariza. 1987. Anticarcinogens from fried ground beef: Heat-altered derivatives of linoleic acid. Carcinogenesis 8:1881-1887.

Hara, A., and N. S. Radin. 1978. Lipid extraction of tissues with a low toxicity solvent. Anal. Biochem. 90:420-426.

Harvatine, K. J., J. W. Perfield II, and D. E. Bauman. 2009. Expression of enzymes and key regulators of lipid synthesis is upregulated in adipose tissue during CLA-induced milk fat depression in dairy cows. J. Nutr. 139:849-854.

Hayirli, A., and R. R. Grummer. 2004. Factors affecting dry matter intake prepartum in relationship to etiology of peripartum lipid-related metabolic disorders: A review. Can. J. Anim. Sci. 84:337-347.

Houseknecht, K. L., J. P. Vanden Heuvel, S. Y. Moya-Camarena, C P. Portocarrero, L. W. Peck, K. P. Nickel, and M. A. Belury. 1998 Dietary conjugated linoleic acid normalizes impaired glucose tolerance in the Zucker diabetic fatty fa/fa rat. Biochem. Biophys. Res. Commun. 244:678-682.

Katoh, N. 2002. Relevance of apolipoproteins in the development of fatty liver and fatty liver-related peripartum diseases in dairy cows. J. Vet. Med. Sci. 64:293-307.

Kay, J. K., J. R. Roche, C. E. Moore, and L. H. Baumgard. 2006. Effects of dietary conjugated linoleic acid on production and metabolic parameters in transition dairy cows grazing fresh pasture. J. Dairy Res. 73:367-377.

Lee, K. N., D. Kritchevsky, and M. W. Pariza. 1994. Conjugated linoleic acid and atherosclerosis in rabbits. Atherosclerosis 108:19-25.

Livak, K. J., and T. D. Schmittgen. 2001. Analysis of relative gene expression data using real-time quantitative PCR and the $2^{-\Delta \Delta C}$ method. Methods 25:402-408.

Loor, J. J., and J. H. Herbein. 2003. Reduced fatty acid synthesis and desaturation due to exogenous trans10, cis12-CLA in cows fed oleic or linoleic oil. J. Dairy Sci. 86:1354-1369.

Mandard, S., M. Müller, and S. Kersten. 2004. Peroxisome proliferatoractivated receptor $\alpha$ target genes. Cell. Mol. Life Sci. 61:393-416.

Medeiros, S. R., D. E. Oliveira, L. J. M. Aroeira, M. A. McGuire, D. E. Bauman, and D. P. D. Lanna. 2010. Effects of dietary supplementation of rumen-protected conjugated linoleic acid to grazing cows in early lactation. J. Dairy Sci. 93:1126-1137.

Miranda, J., A. Fernández-Quintela, I. Churruca, V. M. Rodríguez, E. Simón, and M. P. Portillo. 2009. Hepatomegaly induced by trans-10,cis-12 conjugated linoleic acid in adult hamsters fed an atherogenic diet is not associated with steatosis. J. Am. Coll. Nutr. 28:43-49.

Moore, C. E., H. C. Hafliger, O. B. Mendivil, S. R. Sanders, D. E. Bauman, and L. H. Baumgard. 2004. Increasing amounts of conjugated linoleic acid progressively reduces milk fat synthesis immediately postpartum. J. Dairy Sci. 87:1886-1895.

Moore, C. E., J. K. Kay, R. J. Collier, M. J. VanBaale, and L. H. Baumgard. 2005. Effect of supplemental conjugated linoleic acids on heat-stressed Brown Swiss and Holstein cows. J. Dairy Sci. 88:1732-1740.

Moya-Camarena, S. Y., J. P. Vanden Heuvel, and M. A. Belury. 1999a. Conjugated linoleic acid activates peroxisome proliferator-activated receptor $\alpha$ and $\beta$ subtypes but does not induce hepatic peroxisome proliferation in Sprague-Dawley rats. Biochim. Biophys. Acta 1436:331-342.

Moya-Camarena, S. Y., J. P. Vanden Heuvel, S. G. Blanchard, L. A. Leesnitzer, and M. A. Belury. 1999b. Conjugated linoleic acid is a potent naturally occurring ligand and activator of PPAR $\alpha . \mathrm{J}$ Lipid Res. 40:1426-1433.

Naumann, K., R. Bassler, R. Seibold, and C. Barth. 2000. Die chemische Untersuchung von Futtermitteln, Methodenbuch Bd. III. Verband Deutscher Landwirtschaftlicher Untersuchungs- und Forschungsanstalten. VDLUFA-Press, Darmstadt, Germany.

Odens, L. J., R. Burgos, M. Innocenti, M. J. VanBaale, and L. H. Baumgard. 2007. Effects of varying doses of supplemental conjugated linoleic acid on production and energetic variables during the transition period. J. Dairy Sci. 90:293-305.

Pappritz, J., U. Meyer, R. Kramer, E. Weber, G. Jahreis, J. Rehage, G. Flachowsky, and S. Dänicke. 2011. Effects of long-term supplementation of dairy cow diets with rumen-protected conjugated linoleic acids (CLA) on performance, metabolic parameters and fatty acid profile in milk fat. Arch. Anim. Nutr. 65:89-107.

Perfield, J. W. II, G. Bernal-Santos, T. R. Overton, and D. E. Bauman. 2002. Effects of dietary supplementation of rumen-protected conjugated linoleic acid in dairy cows during established lactation. J. Dairy Sci. 85:2609-2617.

Perfield, J. W. II, A. L. Lock, J. M. Griinari, A. Saebø, P. Delmonte, D. A. Dwyer, and D. E. Bauman. 2007. Trans-9, cis-11 conjugated linoleic acid reduces milk fat synthesis in lactating dairy cows. J. Dairy Sci. 90:2211-2218.

Piperova, L. S., U. Moallem, B. B. Teter, J. Sampugna, M. P. Yurawecz, K. M. Morehouse, D. Luchini, and R. A. Erdman. 2004. Changes in milk fat in response to dietary supplementation with calcium salts of trans-18:1 or conjugated linoleic fatty acids in lactating dairy cows. J. Dairy Sci. 87:3836-3844.

Ringseis, R., D. Saal, A. Müller, H. Steinhart, and K. Eder. 2004. Dietary conjugated linoleic acids lower the triacylglycerol concentration in the milk of lactating rats and impair the growth and increase the mortality of their suckling pups. J. Nutr. 134:33273334 .

Schwarz, F. J., T. Liermann, and A. M. Pfeiffer. 2007. Effect of rumenprotected conjugated linoleic acid in combination with propylene glycol or rumen protected fat on performance and metabolic parameters of early lactation dairy cows. Pages $155-156$ in 2nd International Symposium on Energy and Protein Metabolism and Nutrition, Vichy, France. I. Ortigues-Marty, ed. Wageningen Academic Publishers, Wageningen, the Netherlands.

Selberg, K. T., A. C. Lowe, C. R. Staples, N. D. Luchini, and L. Badinga. 2004. Production and metabolic responses of periparturient Holstein cows to dietary conjugated linoleic acid and trans-octadecenoic acids. J. Dairy Sci. 87:158-168.

Shibani, M., G. Schlegel, E. Most, F. J. Schwarz, R. Ringseis, and K. Eder. 2011. Effect of a rumen-protected conjugated linoleic acid mixture on hepatic lipid metabolism in heifers. J. Anim. Physiol. Anim. Nutr. (Berl.) http://dx.doi.org/10.1111/j.14390396.2011.01175.x.

Stangl, G. I. 2000. High dietary levels of a conjugated linoleic acid mixture alter hepatic glycerophospholipid class profile and cholesterol-carrying serum lipoproteins of rats. J. Nutr. Biochem. 11:184-191.

Tsuboyama-Kasaoka, N., M. Takahashi, K. Tanemura, H. J. Kim, T. Tange, H. Okuyama, M. Kasai, S. Ikemoto, and O. Ezaki. 2000. Conjugated linoleic acid supplementation reduces adipose tissue by apoptosis and develops lipodystrophy in mice. Diabetes 49:1534-1542.

Vandesompele, J., K. De Preter, F. Pattyn, B. Poppe, N. Van Roy, A. De Paepe, and F. Speleman. 2002. Accurate normalization of realtime quantitative RT-PCR data by geometric averaging of multiple internal control genes. Genome Biol. 3:RESEARCH0034.

Weerasinghe, W. M., R. G. Wilkinson, A. L. Lock, M. J. de Veth, D. E. Bauman, and L. A. Sinclair. 2012. Effect of a supplement containing trans-10,cis-12 conjugated linoleic acid on the performance of dairy ewes fed 2 levels of metabolizable protein and at a restricted energy intake. J. Dairy Sci. 95:109-116. 